\title{
The Semiotics of New Era Poetry: Estonian Instagram and Rap Poetry
}

\section{Rebekka Lotman*}

\begin{abstract}
Mikhail Gasparov concludes his monograph "A History of European Versification" with the recognition that in the development of particular verse forms in each tradition of poetry, there is a permanent interaction between two types of poetry: those of oral popular and bookish culture. The forms engendered by popular culture are assimilated by bookish culture, while those engendered by literary culture descend into popular culture (Gasparov 1996: 295). Here, folk poetry represents oral popular poetry, and literary poetry represents poetry published in books. Over the last decade, and especially during the last five years, the importance of lyrical poetry as an art form in Western culture has grown precisely due to the widespread distribution of both types of poetry - oral and written. Yet oral poetry is no longer marked by folklore, and the primary medium of the written poetry is no longer books - we can see that rap poetry and digital poetry, especially Instapoetry (Instagram poetry), are increasingly occupying a central position. However, bookish poetry is also rising, thanks to the latter. The growing popularity of both subgenres of poetry is associated with the emergence of new media: the platform of the first is audio and visual media (SoundCloud, Spotify, YouTube) and of the second is textual and visual media (at first Tumblr, now primarily Twitter, Instagram, and Facebook).

This article examines attitudes and issues related to the emergence of this new era poetry and outlines its poetics from a semiotic perspective. The analysis focuses on Estonian Instagram poetry and rap, studying how these subtypes of poetry, which originate from English-speaking cultures, have emerged after a time gap in smaller literature and have changed the audience, the authors, and the meaning-making of poetry.
\end{abstract}

Keywords: digital literature, Instapoetry, rap poetry, poetics, semiotics of poetry

* Author's address: Rebekka Lotman, Institute of Cultural Research, University of Tartu, Ülikooli 16, 51003, Tartu, Estonia, email: rebekka.lotman@ut.ee. 


\section{Is it poetry at all?}

There are three prevailing viewpoints about poetry on social media, especially Instagram poetry. According to the first, it is not real poetry, but according to the second and less-common view, it saves poetry as a literary genre. The third holds that it is not real poetry but saves poetry by leading to real poetry. ${ }^{1}$

The first viewpoint is common in Estonian critical discourse and elsewhere. The following article title is characteristic of it: "Few read poetry, but millions read Rupi Kaur" (Rao 2017). Instapoetry is framed as the opposite of highvalue literary poetry. Rebecca Watts has named it "artless" poetry that follows the logic of consumer society and is oriented toward selling (Watts 2008). Thus, it is not an art form anymore but a commodity.

Journalistic experiments that attempt to prove that it is not an actual genre of poetry but something that can be faked, i. e., a forgery, also point to Instapoetry as non-poetry. Such an experiment was conducted, for example, by a journalist working for the Canadian American lifestyle and culture magazine Vice who "decided to find out whether Instagram poetry took real talent, or if the whole thing is a sham, by becoming the worst poet the Internet has ever seen." He published one hundred poems under the pseudonym Raven S. (@ravenstarespoetry) in four weeks. He admitted that it was incredibly easy to create these poems: "There were no standards, aside from the deliberate lack of any" The author said that although these verses were insincere, the readers' reactions were genuine, valid, and sincere (Lloyd 2019). Within a month, he gained more than one thousand followers, and each post has received 50-100 likes. One of the most popular raises a question about poetry itself: "is / this / a / poem? // - Raven S." It is noteworthy that he used typewriter font in his poetry posts.

A few months later, a similar experiment was done in Estonia's biggest weekly newspaper, Eesti Ekspress, by an anonymous author grafomaniakk who was intrigued by the success of local Instapoet Nete Tiitsaar. Tiitsaar gained thousands of followers by posting photographs of herself in erotic poses and writing poetry that, according to Alvar Loog, has a stimulating effect on those "who usually don't read belles-lettres, especially poetry" (Loog 2019). The journalist from Eesti Ekspress described also Tiitsaar's reception in social media: the "real" poets and writers had mocked her with pleasure and labeled her - in the best case - a successful seller and not a serious poetess. In this

\footnotetext{
1 These viewpoints are related to the problematics of the distinction between amateur and professional or high poetry. Social media poetry is often seen as falling into the first category. Analyses of qualitative differences between these two types of texts do not fall within this article's scope, which seeks to describe the semiotic mechanisms of digitally published poetry.
} 
article, Tiitsaar's works are named as "poems" (in quotes), signaling the ironic use of the word. As a journalistic experiment, the author of the article started publishing "relatively simple sentences" or online poems consisting of three verses (@grafomaniakk), for example: „kui sul on sees mustvalge film / siis ära loodagi näha värvipilte" ("if you have a black and white film inside / don't even expect to see color pictures"). The visual side of the posts was important, and they alternated between images and texts. grafomaniakk also gained more than 1,000 followers in a short time (\#grafomaniakk 2019).

It is worth noting that the most famous Estonian Instapoet, Lauri Räpp, also belongs to this group. He has confirmed that he does not consider himself a real poet. "For me, the poet is Doris Kareva, Indrek Hirv or Betti Alver. I am more of an amateur" (Lõbu 2021).

Often, in academic discussions, we can see this viewpoint functioning implicitly through exclusion, for example, in defining or delimiting poetry. In an article about 21st-century Estonian literature, literary scholar Märt Väljataga compiled a list of authors who form the core of today's Estonian writers. He names nearly 50 individuals, of whom 29 have published poetry, and the list is based on the annual nominations and awards of the Cultural Endowment of Estonia (Väljataga 2021). Thus, it consists only of award-winning and recognized literary poets who also form the core of writers whose books are reviewed in local literary magazines. There is no mention of Instagram authors or rappers, who are probably considered amateurs.

Lili Pâquet points out that academic scholarship has largely ignored Instagram poets, considering this subgenre too mass-market and uncultured for extended evaluation. "The elitism of this kind of response excludes intriguing ideas about the poetry that is being sold to millions of readers in a time when poetry is supposedly perishing" (Pâquet 2019: 310-311). In Estonia, digital literature has been studied through multiple perspectives by Piret Viires, who has written about the emergence of digital modernism (Viires 2013), the periodization of digital literature (Viires 2017), and the functions and main characteristics of social media poetry (Viires 2020), on which this analysis is partly based.

The second viewpoint, that Instagram saves poetry as an art form, is expressed, for example, by Alex Gurtis in his article "Instapoetry - the polarizing new poetry style that is making poetry relevant again." It begins with the statement, "Poetry is dead, long live poetry." Gurtis sees the essential difference between two types of poetry: traditional literary poetry and Instapoetry. However, he insists that one should not argue whether it is poetry at all but rather study it. "This style is now canon everywhere but academia and 
accomplishes something they only could have dreamed of - made poetry popular" (Gurtis 2018).

On the other hand, this approach is often accompanied by negative criticism. For example, an article entitled "How Instagram saved poetry" (Hill, Yuan 2018) states in the lead, "Social media is turning an art form into an industry." The article describes how most legendary poets, like William Carlos Williams, who was also a doctor, have always split their life between two duties: making a living and making art. In the authors' opinion, Rupi Kaur started the change: since the publication of her poetry collection, milk \& honey, poetry has become the fastest growing category in book publishing in the Englishspeaking world. However, in the Estonian context, it should be noted that for professional and recognized writers, there is a system of annual creative grants (for about 50 authors) and biennially awarded writers' salaries (for five authors), providing an opportunity to earn some additional income from writing poems. Estonian digital media and rap poets, on the other hand, must work for a living because here only a few authors (for example, Lauri Räpp) are able to gain sales revenue.

The third viewpoint is expressed, for example, by the editor of the poetry magazine The Rialto, Rishi Dastidar. "I think it's great if people are enjoying poetry through social media, but the next step would be to read more poetry and understand what else is out there. Contemporary poets offline are incredibly vibrant - it's just directing people into that world" (Qureshi 2015). In Estonian criticism, this viewpoint is represented by Hanna-Linda Korp in her article "Poetryless poetry saves poetry." Korp writes that young people read poetry not always in a book, but more often on social media. The article concludes, "I do not believe that reading poetry with simple content and form on Instagram makes you poorer: in the end, Instapoetry is a transitional form from the reader's, not poetry's point of view" (Korp 2019). The author expresses hope that the reader will at some point turn from this "poetryless" poetry to real poetry, and the poetry itself has not changed.

Contemporary oral poetry culture in the form of rap, on the other hand, is more often recognized as a form of real poetry, and several voluminous monographs have been published on its poetics (e. g., Pate 2010). Thus far, no considerable studies have been published on rap in Estonia. However, some bachelor works on rap poetry have been written, and one master thesis is being written now. Nevertheless, critiques published in cultural magazines confirm that Estonian rap belongs to real poetry. Jürgen Rooste has explicitly worded this in his review of Estonian rapper Beebilõust's lyrics, which begins with the assertion that "Rap is at least as much poetry as all folklore." Thereupon, Rooste places Beebilõust's poetry among Estonian "high poetry": "Thus, next 
to Liiv or Viiding or Koidula or Kareva or Ehin, we also have Beebilõust, whose footprint and skull shape is even more familiar to the young 'reader' who is touched by the poetry" (Rooste 2017). Unlike Lauri Räpp, Beebilõust intends his work to be understood as real poetry, and he has always said that he wanted to be a poet. "And he is," concludes Rooste (2017). A collection of Estonian rap texts (2006) also received many positive reviews (e. g., Vaher 2006).

On one occasion, the lyrics sheet of a rap CD has even been nominated for the Cultural Endowment of Estonia's Literary Prize: Chalice's Taevas ja perse (Heaven and the Ass, 2007). It was an exception that received much attention. According to Sirje Olesk, the chairman of the jury, it was nominated not only to highlight oral poetry but also to make a deliberately challenging choice. She explained, "Adding Chalice to the nominees should show that there is music in which words are almost as crucial as in printed poetry. It also seemed a rather intriguing step for us" (Peegel 2008). However, it has remained a single act, and rap poets and Instapoets tend to be left out of the Estonian literary field unless they publish their texts as separate books.

Another reason for greater recognition of rap as poetry probably results from the fact that it is a much older phenomenon than social media poetry the first Estonian rapper, Cool D, released his album in 1994, and the boom started ten years later when Chalice released Ühendatud inimesed (Connected People, 2003), and the musical group Toe Tag released an album with Genka's innovative rhymes called Legendaarne (Legendary, 2004). In this new decade, however, the popularity of rap has increased both among listeners and creators, and this is largely due to the possibilities of new media.

The fact is that these two seemingly different directions in poetry Instagram poetry and rap - have brought poetry as a literary genre to a broader population, especially to the younger generation, making rhyming and reading poetry more popular among them.

\section{Numbers and authors}

Statistics clearly show the new arrival of poetry in English-speaking literature. A study by the U.S. National Endowment for the Arts analyzed American cultural consumption up to and including 2017. It turned out that until 2012, the number of poetry readers had constantly been decreasing. In 1992, 17\% of respondents had read at least one work of poetry, but in 2012, this number had reduced to 6.7\% (National Endowment for the Arts 2019). Nevertheless, for the first time in the period covered by this study, the number of poetry 
readers began to grow again with the rise of digital literature after 2012, reaching $12 \%$ by 2017.

More importantly, there has been a demographic shift: since 2012, the majority of poetry readers belong to the 18-24 age group, in which the number of poetry readers has more than doubled. These numbers have also risen greatly among African-Americans, Asian-Americans, and other non-white groups, reaching an all-time high. Not only has the number of people reading poetry increased with university education, but more people without higher education are since then interested in poetry (Maher 2018, National Endowment for the Arts 2019). Thus, one can conclude that poetry is not winning back old readers but has started to expand its reach among new generations, different ethnic groups, and people with different levels of education.

The popularity of poetry has grown even more since this survey. For example, according to Nielsen BookScan, a U.K. book sales monitor, sales of poetry books rose by more than $40 \%$ between 2015 and 2020 , with $41 \%$ of buyers in the13-22 age group and predominantly female. The best-selling author was Instagram poet Rupi Kaur, who now has 4.4 million followers on her social media account. She has become the world's best-selling poet (Ferguson 2019). Interestingly, the publishers at first did not apprehend this turn; Rupi Kaur could not find a publisher, so she was forced to self-publish her first collection, milk \& honey (2014). Behind the rest of the sales figures, there are also many Instapoets, although works by Leonard Cohen, John Cooper Clarke, Seamus Heaney, Carol Ann Duffy, and Homer sold many copies (Ferguson 2019).

The digital reading platform, 24symbols, which contains more than 500,000 e-books, has also described the emergence of Instapoets as the most powerful trend of recent times. For example, in 2018, five of the fifteen most-read books were poetry collections. "The young poets prove that poetry is alive and well and have opened the doors for a new and large audience," says the website. Again, several Instapoets who later published their texts in books reached the top of the sales charts (24symbols 2019).

Recently, the pandemic has also expanded the interest in poetry; for example, according to Jennifer Benka, president of the American Academy of Poets, the number of visitors to the website Poets.org increased by a quarter from March 1, 2020 to January 25, 2021. Amanda Gorman's poem “The Hill We Climb", read at the inauguration ceremony of U.S. President Joe Biden, went viral thanks to new media: she gained 2 million Instagram followers in one day, and millions of people shared her poem on Twitter. As a result of these processes, we can see new arrangements of poetry books in shops: once again, they are placed at the front of bookstores (Hines 2021). We are witnessing a 
renaissance of poetry - although many scholars and critics do not consider this poetry at all.

The most popular Estonian Instapoet, Lauri Räpp, has more than 21,000 followers, and each of his poems has between 1,000 and 3,000 likes. It is also worth noting that Räpp has a master's degree in marketing. The opening text of his website states, "Are you looking for an experienced copywriter who would write you compelling texts? In this case, you are in the right place" (www.laurirapp.ee). The anonymous multimedia artist @aegruum (timespace) who publishes haikus, has more than 10,000 followers, and each poem has more than one thousand views (this author uses dynamic Instagram posts). Gerda Laura Liiv (@gerdalaura) has more than 3,200 followers. Other Estonian Instapoets(@armutupostiljon, @sumemadepale, @luulestviidud, @luulelend, @ohakalind, @ohakalind, @heraluule, @maarjaluulud, etc.) have fewer followers, but both the number of Instapoets and their audience is increasing. Given the fact that the print run of Estonian poetry books is often around 300, if not less - one thousand followers is already a remarkable number of readers.

In addition, mention should be made of the master of puns, Keiti Vilms (@keitivilms, 15,500 followers on Instagram). Vilms posts funny wordplays, usually based on common phrases, proverbs, sayings, poetry classics and poems by forgotten authors, literary recommendations, as well as pictures of herself and bizarre and exciting finds from dictionaries, the press, shops, other places. She has also published her online posts as a book, @keitivilms. Eesti esimene säutsukogumik (Estonia's First Tweet Collection, 2017), which was a sales success.

In line with trends in the English-speaking world, Instapoets have increased the sales of poetry books in Estonia. First came translated poetry books by Rupi Kaur (honey \& milk was published in Estonian 2018). Then in 2021, Lauri Räpp published Lihtsate asjade tähtsus (Importance of Simple Things 2021), which has been a bestseller in all the most significant book chains and stores. It has surpassed, for example, the sales of the biographical book about the divorce of famous Estonian journalists Heidit Kaio and Priit Kuusk, which was published at the same time and received high coverage in the paper and digital media, as well as in national broadcasting. Räpp's poetry book has created a precedent and has outperformed sensational biographies, cookbooks, and other popular books and genres. The first edition of Lauri Räpp's poetry collection (with a print run of 2,500 copies) sold out within a few weeks, and by the end of the next month the second and the third printing also ran out; According to the author, the publisher is already planning a fourth edition. Anonymous poet-artist aegruum (Aegruum, [Time-space] 2020) and Gerda 
Laura Liiv (Enne, [Before] 2020; sold out) have also entered the world of published books from the Internet, and their books have been popular.

Behind the popularity of rap poetry is also mainly new media, primarily YouTube. A new wave of rap emerged, on the one hand, with professional production under the influence of the previously mentioned rapper Genka and his group Toe Tag, but on the other hand, amateur rappers also played a role: for example, fun rap artist MC Vimpel with the song "botased kuluvad" ("The sneakers are wearing down", 2004, currently with almost 650,000 views on YouTube). In addition, at the end of the last decade, Estonian rap battles began to appear on YouTube channels, and young rappers of the present day grew up watching them. The music environments SoundCloud and Spotify contributed to further growth. In December 2021, the initiator of the boom, Genka, had more than 21,000 listeners on Spotify. Nublu, the most popular rap artist of recent times, gained almost 164,000 listeners in December (6630 subscribers on SoundCloud), Pluuto had around 28,000 listeners (3,800 subscribers on SoundCloud), \$ipelga14 had more than 6,500 listeners (more than 4,055 subscribers on SoundCloud), and väike pd had 4,600 listeners (2570 on SoundCloud). With these numbers, Estonian rappers are leading the local music charts (see Nestor 2019).

\section{The semiotic mechanisms of the new poetry}

Each new platform - newspaper, book, radio, television, or Internet - inevitably transforms poetry itself (cf. Chasar 2010). It changes the meaning-making of the poem - its poetics and pragmatics, including the communicative situation and textual relations. Piret Viires has identified four main features of social media literature: democratization (everyone can publish online), participatory culture, multimodality, and ephemerality (Viires 2020). In the following analyses, I envisage the semiotic mechanisms of digital era poetry by expanding Viires' approach. I have distinguished nine more or less intertwined levels that help to define the turn to poetry taking place through social media and rap in the 21 st century. 


\section{The primacy of a single poem}

During most of the long history of poetry, a single poem, not a collection of poetry, has taken primary place in lyric poetry - it means that the central unit has been a separate poem, not a bouquet of poetry. As Kristi Viiding has pointed out, this affects the poem's meaning: text published within a poetry book belongs to a broader system, is part of a whole, and this whole forms a kind of implicit ars poetica that that is expressed through each individual poem. According to Viiding, in Livonia the transition from single poems to collecting and publishing many poems together took place in early modern humanist literature during the 16th and 17th centuries (Viiding 2021). In the case of poetry written in the Estonian language, this shift took place at the end of the 19th century or even at the beginning of the 20th century. Before that, the emphasis was on the individual poem that first appeared in the press and only afterward in a poetry collection. Poetry collections have been prominent for most of the 20th century; these poems are part of a conceptual whole formed within the poetry collection.

In 21st-century digital poetry, however, there has been a turn back to the individual poem, again changing how the poem is perceived. In the case of both Instagram poetry and Soundcloud's oral poetry, i. e. rap the emphasis is now on a single text. In music, online streaming has created a so-called post-album era. This means that one individual work at a time is presented to the reader/listener. This shift has consequences for the text itself. In the case of a poetry book or album, each poem expands the meaning of the others inside the same edition; it has a broader concept and poetics. Also, the poem's position in the book is significant (the beginning and end are always marked strongly). Yet in the case of a text published alone the boundaries of a poem lie more strictly within this individual text. Secondly, the poem published individually earns more time/attention, as it remains a separate experience for the reader/listener. Although poems published online are sometimes later published in a book, and a concert or album follows a song that appears first on SoundCloud, the single work is primary, and this collection is secondary.

\section{Two-way communication}

The communication scheme of a traditional work of poetry is one-way, as Roman Jakobson has put it: the sender (poet) sends a message (poem) to the recipient (reader). According to Jakobson, in complement to these three parts, there are three more components required for understanding the meaning of a 
poem: contact (the physical channel of the poem), context (referential meaning), and code (language use, metalinguistic level) (Jakobson 1960). Although in Jakobson's model, this communication is one-way, his six-part scheme helps to explain the meaning-making functions of the poetics and communication of new media poetry.

A shift has occurred due to a change in the communication channel itself, and its role here is more critical than in conventional poetry. The different possibilities for the various communication channels affect the meaning of the other levels of the message (poem) and their interrelations. For example, online poetry favors using emoticons, Twitter poetry determines the length of the text, and Instagram influences the code by adding a vital visual aspect to the poem. In addition, the communication process of the poem has transformed. According to the reader-response theory that emerged in the 1960s, the emphasis on meaning creation moved from author to reader (see, for example, Iser 1974). In social media literature, the reader-author relationship is bidirectional: both the reader/listener and the author reply to the poem's comments. The reader is in direct contact with the author and is present with them in the same medium.

Hence, Piret Viires has linked social media literature to the concept of participatory culture. "One of the most significant manifestations of participatory culture in social media literature is interactivity, the dynamics of the author-reader relationship - the participation of readers in commenting on works, expressing their opinion or participating in the process of creating a work" (Viires 2020: 223). It is very common that Instapoets communicate with their readers by answering or liking their comments. Lauri Räpp occasionally replies verbally to remarks but almost exclusively marks them as pleasing, thus confirming his approval of these texts on his wall. In turn, comments can affect the meaning of the posted poem. For example, on August 31, 2021, Gerda Laura Liiv posted a poem about the impossibility of speaking out: "ei oska endast enam teistele rääkida / sisemine monoloog välja ei kostu" ("I can't talk about myself to others anymore / the inner monologue doesn't come out"). Next to the post, she explains, "i don't know how i am doing and what have $i$ done, and i don't know what to say". One reader responds, "Sometimes silence says more than a thousand words or a thousand words come after silence!" The poet replies to this comment, "well said! I hope these 1000 words are on their way to met?" This conversation remains on the wall next to the poem, expanding its meaning - reaffirming the impossibility of speaking in many words adds unintended irony to the poem. 


\section{Instant emotive communities}

In Jakobson's model, the sender or author of a text expresses the emotive (also expressive) function, which represents the speaker's attitude toward what he is talking about, his attitudes, and emotions (Jakobson 1960). Joep Leerssen has spoken about the emotive communities created by a shared experience of lyric poetry: while silent reading is private, performative oral performance is public, creating an emotive community between the author and the reader (e. g., Baltic song festivals). In the case of conventionally written poetry, singing together is necessary for such a community of shared emotion to emerge. This function of lyrical poetry was influential in creating a sense of nationality in the Romantic era (Leerssen 2021).

In the case of social media poetry, this performative effect arises simultaneously when the text is published, immediately (re)creating emotive communities: the followers of the poet-artist, the subscribers to his channel, already belong to one community. In the case of rap, these communities also meet in real life; at concerts, the audience is largely made up of subscribers and followers of these artists on online channels. In addition, this feeling of belonging is confirmed by liking and sharing a poem or leaving a public comment on the wall of a media channel.

For example, on May 1, 2021, Lauri Räpp published a poem that begins: "mu kallis / kuidas sul seal läheb / meil siin vahtrad / tilguvad vett / jah, mu hääl on veidi kähe / joon kummeliteed / kus tilgake vett" ("my dear / how are you doing there / our maples here / are dripping water / yes, my voice is a little hoarse / I am drinking chamomile tea / with a drop of water"). One reader adds a comment, "So, someone should now create music for this poem." The author replies, "I would like the idea. And go find out, maybe someone will create (-)." Another reader adds, "I believe that it has already made many hearts ring, and this music will soon be heard in others." Thus, this sense of community is also emphasized here in a verbal message.

Just as the poem's communication in the new media is bidirectional - not only does the author write to the readers, but the reader participates in its meaning as well - so is the sense of community. Kovalik and Curwood have researched the attitudes and perceptions of young poets (ages 13-25) an they emphasized that the sense of community and interactivity was important also to poets, especially in regard to feedback. $93 \%$ had received feedback on their poems, $89 \%$ had given feedback to others; the most common method was commenting, followed by private direct messages to the author (Kovalik, Curwood 2019: 190). 


\section{The new lyrical self}

The distance between the reader and the poet has decreased in association with the previous two points. Both in Instapoetry and in rap poetry, the author is more directly present than before. Social media poetry is not mediated by the publisher (poetry published in the book is laid out and proofread by professionals, the reader buys it from anonymous sellers from the bookshops, etc). In the case of Instagram poetry, the authors directly give the text to the recipients with their own design and voice. It is a straightforward communication in which the performer addresses the audience directly.

Here we can distinguish between two opposite directions. First, Instagram allows complete anonymity. In the case of a printed book, this is not impossible but quite tricky (you need to pay for the printing, contact the ISBN center, and then market the book and make arrangements with the bookstores). On social media, you can create your persona, which also is performed as a lyrical self, and no one knows to whom that voice belongs in real life. The most famous example here in Estonian context is @aegruum.

Another type of authors associates their social media poetry posts directly with their real life persons. They share personal information between poems and songs, including posting pictures of themselves. Some share their views on world events, opinions on political processes, and personal life. This marks the substantial rise of the lyrical self: "I speak to you", and this "I" can easily equate the voice heard in poems with the author's voice. In the case of rap, personality has played a significant role in the reception of Estonian YouTube rappers - they have published music videos and video posts sharing their attitudes, opinions, and jokes, and their personality is directly associated with their music. It is strongly perceived that the rapper expresses their ideas and thoughts, and their lyrical subject corresponds to their own voice.

In the third case, the author is known by name; they may share pictures, but at the same time, they keep their attitudes, political beliefs, and personal life to themselves. The account is not anonymous, but the poets maintain their privacy. This type of social media account belongs to Lauri Räpp, whose poems express timeless topics and states of mind. The attitudes displayed in his poetry do not relate to social or political issues that often polarize society. 


\section{The intention of genuine expression}

The new lyrical self emphasizes authenticity in both oral and written social media poetry. In Instagram poetry, we can often meet simple and worn-out metaphors. Although the authors and readers underline the authenticity of Instapoems - they are based on genuine feelings - they have also been criticized as literary clichés or even plagiarism (see Nohria 2019). For example, the poet Nayyrah Waheed, who started posting poems on Tumblr at the same time as Rupi Kaur, has accused the latter of plagiarism because she was the first to use the metaphor of honey in this social media platform. Thus, the terms "genuine" and "plagiarism" are both used to describe this type of poetry. Yet the contradiction here is only on the surface; the true and immediate feelings expressed in these poems are not usually so unique but universal and have already been used repeatedly in poetry.

Here one can see a resemblance to the poetics of folklore formulas studied by Milman Parry and Albert Lord, showing that ancient poetry is not a matter of borrowing or plagiarism but instead of orally circulating formulas that other poets interwove in their texts. According to Parry, a formula is "a group of words which is regularly employed under the same metrical conditions to express a given essential idea" (Parry 1930: 80). So, in the case of Instagram poetry, it would be fruitful to analyze these recurring figures not as features of bookish poetry but similarly to the poetics of folklore formulas, highlighting characteristic patterns.

Due to the tendency to use a typical figurative language in social media poetry, it is easy to parody this kind of work of art, and several authors have done so. For example, the award-winning poet Thom Young discovered that serious and famous poets received little attention, but trivial short poems garnered thousands of followers (Flock 2017). He started parodying this subgenre of poetry on his Instagram account @tyypoet, and it turned out very successful. Now he has over 42,000 followers. The next generation of Instagram poets - who are more ironic and witty - is already emerging in the Englishspeaking world (Leach 2021).

On the other hand, in oral rap poetry, sincerity signifies eloquence and not censoring yourself on any level. The rap poets use the words they want; their rhyming words are their personal items and genuine expression. They aim to offer surprising rhymes, and the use of clichés and worn-out rhymes is taboo. Authenticity here is marked by saying things as they are with the words the rapper chooses. 


\section{A particular moment - ephemerality}

Unlike book poetry, publishing a poem on social media is related to a very precise time and space. In the case of books, poetry can also deal with current problems, but it lacks the immediacy characteristic of social media. On Instagram, the artist chooses the exact moment to share their creation with their audience, and it is possible to react and perform instantly. However, this also brings about the temporality of online works: the poem appears in the reader's social media feed, but it sinks into the past like everything else on social media. Piret Viires has pointed out that one of the main attributes of social media poetry is its ephemerality. "Longevity and endurance are not characteristic features of social media platforms. The ephemerality of social media literature is first and foremost determined by technology and is related to the structure and principles of usage in social media platforms" (Viires 2020: 228).

However, most Estonian Instagram poems do not investigate current topics, even though this type of media should encourage this. Timeless themes are preferred: feelings, states of being, images of nature, and philosophical insights. In addition, the most famous social media poets, Lauri Räpp and aegruum, usually use vocabulary that does not connect the poem with any particular era or place, and no proper names are mentioned. For an example, see aegruum's haiku from June 12, 2020: "enese sisse / ehitan igaviku / täidan sinuga" "inside myself / I build an eternity / filled with you"). Also, poems wondering about poetry itself are quite common, e. g., Elis Laulniit (@ohakalind): "kas luuletajal olema peab hääl / miks ma luul / kui tühi tuul / lihtsalt uluda või välja pääl?” ("does a poet need a voice / why my poetry / like empty wind / may not like wind just howl on the field?"). The exception here is Gerda Laura Liiv, who occasionally brings social critique and politics into her Instagram poetry. She has dedicated a poem to the new Estonian president: "ärge siis unustage / kui alar karis tööle hakkab" ("do not forget / when alar karis starts to work") and another to the current pandemic: "koroona teine laine" ("the second wave of Covid").

On the other hand, rap lyrics feature a wide array of proper names, places, references to contemporary politics and other timely topics and events, and unusual and unexpected vocabulary (which offers novel rhyming possibilities). It often embodies social poetry through the subjective prism of the lyrical self. 


\section{Brevity}

These texts spanning a brief moment are usually short themselves; this tendency can be seen in both social media and new media rap lyrics. While influence can be seen from Twitter (the 140-character limit), other types of social media also induce brevity in the poems. For example, a post's text has to be large enough to be readable on a phone. The poems usually have fewer than ten lines, and longer poems may be up to 16 lines (four verses each consisting of four lines). For the uncommon longer poems (e. g., Lauri Räpp), the solution has been to publish each one as several pictures in one post.

The verse lines also tend to be relatively short. Metrically, the most common form is free verse, often with a verse line consisting of only one, two, or three words. As mentioned, aegruum uses syllabic verse (haikus). In addition to free verse, Lauri Räpp also posts metrical and rhymed poems on Instagram, using dolnik and iambic structures. For longer metrical rhymed units, for example four stressed dolnik, it is common to divide one metric segment visually into several separate verse lines, e.g., "lumi on / ununenud / unistuste / tolm // sa ütlesid / kui tulid / saatjaks / lumetorm" ("snow is / forgotten / dust / of dreams // you said / when you came / accompanied / by the snowstorm"). There are a total of four stressed positions in each stanza, and the last singleworded lines rhyme with each other. However, in most cases, Räpp's stanzas consist of two or three feet.

Rap songs have also gotten shorter with time. For example, Cool D's first album in 1995 had an average song length of 3.9 minutes, and several pieces spanned 6 minutes. Artists releasing music on social media platforms often have songs between 1-2.5 minutes. Rapper Lil Till's average song length on SoundCloud is 2 minutes, and for Pluuto, it is 2.4 minutes. This follows the general trends in the music industry; e. g., for 2019 Billboard top 100 songs, the average length was half a minute shorter than the year before (Trust 2019). ${ }^{2}$

\footnotetext{
2 At the same time we can already see counterreactions to this tendency. For example, Russian popular rapper Oxxxymiron published after a long creative pause on November 1, 2021, on YouTube song "Кто убил Марка?" with a length of 9,5 minutes; in one month it has gained more than 15 million views.
} 


\section{New textual relations}

Postmodern poetic revolution in Estonian literature at the end of the previous century is characterized by maximal literary effects. To understand the full meaning and semantic mechanisms of a postmodern work of poetry, it is necessary for the reader to know the structures that are being deconstructed, intertextual references, etc. In social media poetry, the textual relations have changed, but in different ways in oral and written poetry.

Social media written poetry is characterized by replacing mandatory intertexts with paratexts, which includes the person of the poet, his comments, hashtags that tie the poem into a more extensive web of posts, and tags of other people and places. In a way, Lauri Räpp's posts can be compared to Dante Alighieri's prosimetrical "Vita Nuova" (1294). As Dante described in prose form next to his sonnets, cantos, and ballads the sentiments, thoughts, and intentions he had when writing each poem, in a similar way, Lauri Räpp often includes an explanatory text with a poem, which also belongs to the poem's meaning. For example, on October 1, 2021, he published two poems at once with the caption, "October is outside, and only rust remains of the summer. The smoky breath of fireplaces is in the air, and some early mornings are already crackling under my feet. Autumn's thoughts are sweet like bitter chocolate, and the surrounding somber beauty inspires. Those walks with leaf-fall through the low autumn light and a tin cup warming palms, where peppermint tea is steaming. Life is beautiful, and beauty is in life itself. Share this with the important people. I give you two autumn notes into the October that began today."

Rap lyrics are generally more playful than written social media poetry - the genre uses more possibilities of the language, also, there is strong intertextuality, which can be regarded as a direct dialogue between rap artists. For example, the aforementioned song "botased kuluvad" by MC Vimpel begins with the lines: "Jess palgapäev, ma lähen kohe lolliks, panen vastu hambaid konduktorile trollis" ("Yay, payday, I'm going mad right now, I will punch the conductor in the teeth in the trolley"), then marp\$ responds to this in his song "botased" (sneakers) with the following lines: "Jess palgapäev, ma lähen kohe holli, panen vastu hambaid suva poserile sollis" ("Yay, payday, I'm going to club Hollywood right now, I will punch some random poser in the teeth in the mall"). Here a parallel can be seen with 17th-century French bouts rimés, in which a sonnet had to be written with rhymes given by another person - in the same way rappers respond to each other using the same lines and rhymes. A general distinctive feature of rap lyrics is dialogue, but this interaction arises 
mainly with other texts belonging to the same subculture rather than with the broader literary canon.

Thus, the digital poetry has lost the multilayered nature valued in conventional book poetry or, in other words, it has freed itself from literary boundaries. Väljataga also draws attention to this tendency, however, keeping in mind not the authors who publish elsewhere than books and cultural journals, but poets of youth literary magazine Värske Rõhk. He refers to the falling apart of literary history, which is supported by the fact that young poets seldom mention older poets other than fs or Sveta Grigorjeva. "I think the earlier literary history is no longer perceived as linear, in a way where one poet is followed with another: classics or 'canon' is now simultaneously present in a great museum hall without one author 'growing out' from the other." At the end of the article, he admits:

In no way the end of art and the end of art history precludes the creation of new works of art. They may entertain and teach, but they lack greater ambitions. Perhaps it has always been so, and the inflated talks of the eternity of literature and other similar pretensions are rather a historical deviation. If so, then at least poetry will have a hard time justifying itself because there are not enough audience who would be entertained and taught by contemporary verse (Väljataga 2021).

Nevertheless, as we have seen, the poetry that escaped linearity has brought a new rise of this art form in the 21 st century.

\section{Visuality/intonation}

Instagram poetry emphasizes the visual side of a text in a special way: each poem is inseparable from its design. Instapoets often use solutions that refer to the age prior to new media, alluding to the authenticity of the work of art: hand-drawn images (Rupi Kaur) and typewriter imitations are widespread (Lauri Räpp, Gerda Laura Liiv, and lesser-known authors like @_piskyy_, @ punktitaluul, and others). These typewriter fonts came into use following the example of Western poets like Knott Gregson (@tylerknott), who has been active on social media since 2009 and has 348,000 followers on Instagram. He not only publishes poems in typewriter font, but they are also on paper that is crumpled or marked in some other way. Thus, the text published on social media adds a connotation of literary poetry not through intertextual references but using design. At the same time, it refers to the pre-computer era of typewriters, which bears in itself the connotation of the "real" (as opposed to the virtual) thing. 
The pun artist Vilms has also stressed the importance of social media posts' visual aspect. "If I post my own pun on Twitter, then I always want it to be in a certain font and that it has a clean white sheet behind it." In addition, Vilms shares the pictures of pages from books on the Internet to create "a certain idea of a book" (Allik 2018).

This also includes the publication of pictures and photos depicting the author or illustrating the poem. Due to the significance of the visual aspect, Pâquet (2019) has noted in Instagram poetry the emergence of one of the oldest literary techniques, ekphrasis.

Dynamic pictures are also used in Instapoetry. For example, Rupi Kaur has used her voice and an animated picture in her poetry design (https:// www.instagram.com/p/CV1F6lqgDqZ/). Dynamically designed (both audibly and visually) poetry among Estonian artists may be found on the account of @aegruum. Piret Viires has agreed with Pâquet by distinguishing multimodality as one of the main features of digital literature (Viires 2020: 224-226).

Rap highlights the oral nature of poetry in a unique way. Intonation is essential, and words that do not rhyme in written poetry are made to rhyme orally, i. e., eye rhyme is replaced by ear rhyme. Here again, the pioneer was Genka, who sometimes rhymes superlong syllables with the short ones: "ja me pappi ei saagi / ja kas on vajaagi" (2004); the correct spelling would be 'vajagi' with the stress on the first syllable, but here we can see the accentual and quantitative shift on the first and the second syllable. In addition, sometimes the boundary between words and non-words is blurred and the voice is distorted (e. g., using auto-tune), turning words into onomatopoeic utterances.

\section{Conclusion}

We are witnessing the rise of the importance of poetry in the 21 st century and its simultaneous transformation. The new era poetry has escaped the institutional and academic corpus where it is prized, but it has returned to the people, especially among the younger generation, through rap music, which has taken the position of traditional oral poetry, and digital poetry, which has taken the place of conventional book poetry. Thus, it can be said that digital poetry has escaped from the traditional literary landscape. While postmodern poetry became elitist, 21 st century digital poetry has freed itself from the chains of literature. A new kind of poetry has emerged that institutional literary circles do not even recognize as poetry; rather, it is seen as some kind of curiosity or a phenomenon that does not belong to the field of poetry but rather is a consumer good or entertainment. 
It is important to note that the change in poetry's meaning-making and communication process is inevitable with the use of new media, regardless of the nature of the poem posted. A classic poem may find a new life and new readers via Instagram, but at the same time, this text enters new mechanisms of meaning. It frees itself from the old system, disregarding academia, the history of poetry, literary movements to which a poem belongs, and other poems by the same author. Instead, the poem's significance now includes the person who shared it, the moment of posting, the styling, the sense of community, the surrounding comments and hashtags, the number of likes, but most importantly, the poem itself - the text without historical context or cultural meaning, only with the message it conveys.

In the new reading experience, the affective function is prominent - how the poem impacts the reader. Thus, social media poetry may not be written in a different way, may not be better or worse by quality than classical pieces of art, but the platform itself imposes a different meaning. Instagram poetry and rap lyrics do not win prizes, and the authors are not publicly funded. However, the so-called institutional poetry, which is valued in many ways, has become a point of interest for a decreasing audience. This is in the essential nature of poetry: to conquer areas of non-poetry, to break out of the framework of what is seen as poetry. In the 20th century, poetry shifted the borders of this form of art playfully inside the realm of literature; the digital poetry of the 21 st century seeks its way out of literature altogether. ${ }^{3}$

\section{References}

\#grafomaniakk 2019. Loe seda artiklit, kui tahad saada kuulsaks instapoeediks ja saada 160 laiki ühe päevaga. In: Eesti Ekspress. 31.12.2019. https://ekspress.delfi. ee/artikkel/88496211/loe-seda-artiklit-kui-tahad-saada-kuulsaks-instapoeediksja-saada-160-laiki-uhe-paevaga

24symbols 2019. InstaPoets are revolutionizing the genre. In: 24symbols. https://www.24symbols.com/24stories/en/instapoets-poetry-digital-age/

3 This research has been supported by the Centre of Excellence in Estonian Studies (European Union, European Regional Development Fund) and is related to the research project "The Factor of Lyrical Poetry in the Formation of Small Literatures" (Estonian Ministry of Education and Research). 
Allik, Heli [interviewer] 2018. Keiti Vilms: sõnad on mind päästnud kõige hullematest kohtadest. In: ERR kultuuriportaal. 17.10.18. https://kultuur.err.ee/869784/keitivilms-sonad-on-mind-paastnud-koige-hullematest-kohtadest

Alter, Alexandra 2015. Web Poets' Society: New Breed Succeeds in Taking Verse Viral. In: The New York Times. 07.11.2015. https://www.nytimes.com/2015/11/08/ business/media/web-poets-society-new-breed-succeeds-in-taking-verse-viral.html

Chasar, Mike 2020. Poetry Unbound. Poems and New Media from the Magic Lantern to Instagram. New York: Columbia University Press.

Ferguson, Donna 2019. Poetry sales soar as political millennials search for clarity. In: The Guardian, 21.01.2019. https://www.theguardian.com/books/2019/jan/21/ poetry-sales-soar-as-political-millennials-search-for-clarity

Flock, Elizabeth 2017. Why this poet is posting meaningless verse on Instagram. In: PBS, 12.06.17.

Gasparov, Mikhail 1996. A History of European Versification. Oxford: Clarendon Press.

Gough, Emily 2021. Market Report - Instapoets and the Rise of Online Poetry. In: Falwriting. 2.08.2021. https://falwriting.com/new-blog/2021/7/29/market-reportinstapoets-and-the-rise-of-online-poetry-by-emily-gough

Gurtis, Alex 2018. Instapoetry - the polarizing new poetry style that is making poetry relevant again. In: Odyssey 10.01.2018. https://www.theodysseyonline.com/instapoetry

Hill, Faith; Yuan, Karen 2018. How Instagram saved poetry. In: The Atlantic. 15.10.2018. https://www.theatlantic.com/technology/archive/2018/10/rupi-kaurinstagram-poet-entrepreneur/572746/

Hines, Morgan 2021. A 'renaissance' is upon us: Interest in poetry on the rise after year of pandemic, chaos. In: USA Today. 8.02.21. https://eu.usatoday.com/story/ entertainment/books/2021/02/08/could-renaissance-coming-poetry-wakepandemic/6256821002/

Iser, Wolfgang 1974. The Implied Reader: Patterns of Communication in Prose Fiction from Bunyan to Beckett. Baltimore: Johns Hopkins University Press.

Jakobson Roman 1960. Closing statement: Linguistics and poetics. In: Sebeok, Thomas A. (ed.), Style in Language. Cambridge, Mass.: MIT Press, 350-377.

Korp, Hanna Linda 2019. Luuletu luule päästab meedia. In: Sirp. 12.07.2019. https://sirp.ee/s1-artiklid/c7-kirjandus/luuletu-luule-paastab-luule/ 
Kovalik, Kate; Curwood, Jen Scott 2019. \#poetryisnotdead: understanding Instagram poetry within a transliteracies framework. In: Literacy 53(4), 185-195. https://doi.org/10.1111/lit.12186

Leach, Samantha 2021. The second wave of Instagram poetry is here. In: Bustle. 18.03.2021. https://www.bustle.com/entertainment/the-second-wave-of-instagram-poetry-is-here

Leerssen, Joep 2021. Emotive communities: The Lyric as form, affect and platform. In: The Factor of Lyrical Poetry in the Formation of Literary Cultures. 14th international conference of the Estonian Association of Comparative Literature. https://www.uttv.ee/naita?id=31748

Lloyd, Andrew 2019. I faked my way as an Instagram poet, and it went bizarrely well. In: Vice. 12.09.19. https://www.vice.com/en/article/zmjmj3/instagram-poetry-becomesuccessful-scam

Loog, Alvar 2019. Autori surm vs autori sarm? In: Postimees. 5.11.19. https://leht.postimees.ee/6819037/autori-surm-vs-autori-sarm

Lõbu, Grete [interviewer] 2021. Sotsiaalmeedia luuletaja Lauri Räpp: kirjutan oma sisetunde pealt. In: Menu 25.10.2021. https://menu.err.ee/1608381785/ sotsiaalmeedia-luuletaja-lauri-rapp-kirjutan-oma-sisetunde-pealt

Maher, John 2018. Can Instagram make poems sell again? In: Publishers Weekly. 02.02.2018. https://www.publishersweekly.com/pw/by-topic/industry-news/ publisher-news/article/75976-can-instagram-make-poems-sell-again.html

National Endowment for the Arts 2019. U.S. Patterns of Arts Participation: A Full Report from the 2017 Survey of Public Participation in the Arts. https://www.arts. gov/sites/default/files/US_Patterns_of_Arts_ParticipationRevised.pdf

Nestor, Siim 2019. Eesti tipp-40 muusikas: SoundCloudi popräpp pommitab Eesti lugude tabelit. In: Eesti Ekspress, 3.06.19. https://ekspress.delfi.ee/ artikkel/86414015/eesti-tipp-40-muusikas-soundcloudi-poprapp-pommitabeesti-lugude-tabelit.

Nohria, Aarushi 2020. Copy and paste by Rupi Kaur. In: The Daily Campus. 19.11.20. https://dailycampus.com/2020/11/19/copy-and-paste-by-rupi-kaur/

Pâquet, Lili 2019. Selfie-Help: The multimodal appeal of Instagram poetry. In: The Journal of Popular Culture 52(2), 296-314. https://doi.org/10.1111/jpcu.12780

Parry, Milman 1930. Studies in the epic technique of oral verse-making. I. Homer and Homeric Style. In: Harvard Studies in Classical Philology 41, 73-147. https://doi.org/10.2307/310626 
Pate, Alexs 2010. In the Heart of the Beat: The Poetry of Rap. African American Cultural Theory and Heritage. Lanham, Maryland, Toronto, Plymouth, UK: The Scarecrow Press.

Peegel, Mari 2008. Chalice esitati kultuurkapitali luulepreemia kandidaadiks. In: Eesti Päevaleht, 7.02.08. https://epl.delfi.ee/artikkel/51118450/chalice-esitatikultuurkapitali-luulepreemia-kandidaadiks

Qureshi, Huma 2015. How do I love thee? Let me Instagram it. In: The Guardian, 23.11.15. https://www.theguardian.com/books/2015/nov/23/instapoets-instagramtwitter-poetry-lang-leav-rupi-kaur-tyler-knott-gregson

Rao, Sonia 2017. Few read poetry, but millions read Rupi Kaur. In: Boston Globe, 11.10.17. https://www.bostonglobe.com/arts/books/2017/10/10/few-read-poetrybut-millions-read-rupi-kaur/WhIaCDVOZJHyWfTMX3uojP/story.html

Rooste, Jürgen 2017. “Täna mo värsid on vihased” ehk Beebilõusta poeesia lühianatoomia. In: Sirp, 16.06.17.

https://sirp.ee/s1-artiklid/c7-kirjandus/tana-mo-varsid-on-vihased/

Trust, Gary 2019. Billboard Hot 100 Top 10s in 2019 are, on average, 30 seconds shorter than last year. In: Billboard, 6.04.19. https://www.billboard.com/pro/hot-100-top-10s-30-seconds-shorter-2019/

Vaher, Berk 2006. Eesti räpptekstide kogumik. In: Eesti Ekspress, 6.06.06. https://ekspress.delfi.ee/artikkel/68997451/eesti-rapptekstide-kogumik

Viires, Piret 2009. The new elite: From digital literature to a printed book. In: Interlitteraria, 14(1), 247-255.

Viires, Piret 2013. Digimodernistlik eesti kirjanik. In: Methis 8(11), 9-21. https://doi.org/10.7592/methis.v8i11.999

Viires, Piret 2017. Digitaalse kirjanduse defineerimisest ja periodiseerimisest. In: Philologia Estonica Tallinnensis 2, 129-145. https://doi.org/10.22601/PET.2017.02.08

Viires, Piret 2020. Uued loomevõimalused internetis. Märkmeid sotsiaalmeedia kirjandusest. In: Methis: Studia humaniora Estonica 21(26), 217-236. https://doi.org/10.7592/methis.v21i26.16917

Väljataga, Märt 2021. Üks korralik kirjandus? Mõttevahetus: XXI sajandi eesti kirjandus. In: Looming 10. https://www.looming.ee/arhiiv/uks-korralik-kirjandus/

Watts, Rebecca 2018. The cult of the noble amateur. In: PN Review 239, 44(3). https://www.pnreview.co.uk/cgi-bin/scribe?item_id=10090 